\title{
CORRUPTION AS A SERIOUS INHIBITOR TO HUMAN RIGHTS REALISATION: A RESPONSE FROM THE UN HUMAN RIGHTS COMMITTEE
}

Assoc. Prof. Vasilka Sancin, Ph. D.*

UDK: $341.231 .14: 343.352$

342.7:343.352(100)

DOI: 10.3935/zpfz.71.1.02

Izvorni znanstveni rad

Primljeno: travanj 2021.

The article first briefly discusses the negative impact of corruption on the enjoyment of human rights, particularly civil and political rights, and States parties' obligations under the International Covenant on Civil and Political Rights (ICCPR), to then focus on a critical analysis of the UN Human Rights Committee's practice (HRC), demonstrating that corruption is no longer only occasionally mentioned within differently focused substantive paragraphs of concluding observations, but features prominently, often as a standalone separate concern, followed by specific and detailed recommendations. Such development signals the recognition by the HRC of important interlinkages between corruption and serious effects on a number of ICCPR's rights. The conclusion offers some thoughts on possible evolution on the issue within the HRC, with the objective of ensuring full realisation and enjoyment of civil and political human rights.

Keywords: human rights; corruption; International Covenant on Civil and Political Rights; UN Human Rights Committee; United Nations Convention against Corruption

* Vasilka Sancin, Ph. D., Associate Professor, Faculty of Law, University of Ljubljana, Poljanski nasip 2, 1000 Ljubljana, Slovenia; vasilka.sancin@pf.uni-lj.si;

ORCID ID: orcid.org/0000-0002-1623-7278

The author is a member of the UN Human Rights Committee; however, the views and assessments expressed in this article are those of the author alone and do not represent the official views of the HRC, except where specifically indicated otherwise. 


\section{INTRODUCTION}

Corruption exists in all countries, irrespective of the economic or political system and their level of development. ${ }^{1}$ While there is no internationally recognized definition of corruption", and some define it as "l'envers de droits de l'homme", what is perceived as corrupt is historically, politically and culturally determined, and undoubtedly comprises behavior that almost all States agreed to criminalize when they ratified the 2003 United Nations Convention against Corruption (UNCAC) ${ }^{4}$, including bribery, embezzlement, misappropriation or other diversion of property, trading in influence, abuse of functions and illicit enrichment. At the heart of these crimes lies the misuse of power in order to obtain an undue advantage for private or political gain, so pathologies in the agency/principal relation are at the heart of the corrupt transaction. ${ }^{5}$

Corruption permeates both public and private spheres, which necessitates a global and systemic approach, including through relevant international organisations. The adverse impact of corruption is recognized throughout the United Nations (UN) system as one of the main challenges to sustainable development ${ }^{6}$ and the realization and enjoyment of human rights. ${ }^{7}$ It has received increasing attention from various UN mechanisms, including the UN General Assembly ${ }^{8}$,

1 See, Corruption and human rights, https://www.ohchr.org/EN/Issues/Development/ GoodGovernance/Pages/Corruption.aspx (5 February 2021).

2 Rose describes corruption as an umbrella concept rather than a legal term of art. Rose, C., International Anti-Corruption Norms, Their Creation and Influence on Domestic legal Systems, Oxford University Press, Oxford, 2015, pp. 7 - 10.

3 Lucchini, R., Universalisme et relativisme dans l'approche de la corruption. L'envers des droits de l'homme, Editions Universitaires Fribourg Suisse, Fribourg, 1995, p. 21.

4 United Nations Convention against Corruption (New York, 31 October 2003), United Nations, Treaty Series, vol. 2349, No. 42146, p. 41.

5 Rose-Ackerman, S. (ed.), International Handbook on the Economics of Corruption, Edward Elgar, Cheltenham, Northampton, 2006, p. xvii.

6 Corruption is a major constraint to the achievement of the Sustainable Development Goals (SDGs) under Agenda 2030 (Transforming our world: the 2030 Agenda for Sustainable Development, A/RES/70/1 (25 September 2015)). Among 17 goals, the one that highlights corruption is SDG 16, aiming to "promote peaceful and inclusive societies for sustainable development, provide access to justice for all and build effective, accountable and inclusive institutions at all levels", only target 16.5 explicitly mentioning corruption: "Substantially reduce corruption and bribery in all their forms".

7 Human Rights Council Resolution 31/14 on 'The role of good governance in the promotion and protection of human rights', A/HRC/RES/31/14 (23 March 2016).

8 The UN General Assembly in June 2020 adopted the resolution 74/276 entitled "Special session of the General Assembly against corruption" and in August 2020, 
the International Law Commission ${ }^{9}$, the UN Human Rights Council ${ }^{10}$ and its subsidiary bodies and mechanisms ${ }^{11}$, other UN treaty bodies ${ }^{12}$, the Office of the High Commissioner for Human Rights (OHCHR $)^{13}$, which are increasingly identifying corruption as a critical factor undermining States' ability to fulfil

the decision 74/568, in which it decided that the special session will be held in June 2021, see https://ungass2021.unodc.org/ungass2021/index.html (27 March 2021).

9 The International Law Commission states that corruption is an exception to immunity of State officials from foreign criminal jurisdiction, along with genocide and crimes against humanity, demonstrating its severity: ILC, Report on the work of the sixty-ninth session (2017), Chapter VII, available here: https://legal.un.org/ilc/ reports/2017/english/chp7.pdf.

10 See, e.g., the following resolutions and decisions of the Council on "the negative impact of corruption on the enjoyment of human rights": A/HRC/RES/35/25 (23 June 2017), A/HRC/RES/29/11 (2 July 2015), A/HRC/DEC/26/115 (10 July 2014) and A/HRC/RES/23/9 (13 June 2013).

11 See, e.g., Final Report on the negative impact of corruption on the enjoyment of human rights, A/HRC/28/73, 5 January 2015; Report of the Special Rapporteur on the right of everyone to the enjoyment of the highest attainable standard of physical and mental health, A/72/137, 14 July 2017; and Report of the Working Group on Arbitrary Detention, A/HRC/10/21, 16 February 2009. Also see: The Human Rights Council Advisory Committee's "Study on utilizing non-repatriated illicit funds with a view to supporting the achievement of the Sustainable Development Goals" (A/HRC/43/66); The Special Rapporteur on the independence of judges and lawyers in A/72/140 and A/67/305; Special Rapporteur on the promotion and protection of the right to freedom of opinion and expression in $\mathrm{A} / 70 / 361$; the Independent Expert on the effects of foreign debt and other related international financial obligations of States on the full enjoyment of all human rights, particularly economic, social and cultural rights in A/HRC/31/61; and the Working Group on Business and Human Rights in A/HRC/44/43. The issue of corruption was also explored during the 2019 UN Forum on Business and Human Rights in sessions titled "Corruption: the business and human rights dimension" and "How business can leverage anti-corruption practices to advance respect for human rights".

12 See, e.g., the following concluding observations of various committees: CAT/C/ AFG/CO/2, para. 29; CEDAW/C/GTM/CO/8-9, para. 12; CCPR/C/PAK/CO/1, para. 31; CCPR/C/MDG/CO/4, para. 11; CCPR/C/HND/CO/2, para. 22; CERD/C/MNG/ CO/19-22, para. 10; CMW/C/MEX/CO/3, para. 23; CMW/C/IDN/CO/1, para. 56; CRC/C/AGO/CO/5-7, para. 9; CRC/C/ARG/CO/5-6, para. 10; CRC/C/NPL/CO/3-5, para. 12; CRC/C/ZWE/CO/2, para. 16; E/C.12/CAF/CO/1, paras. 15 and 16; E/C.12/ TUN/CO/3, para. 48; E/C.12/LBN/CO/2, para. 14.

13 See, e.g., OHCHR, Best practices to counter the negative impact of corruption on the enjoyment of all human rights, A/HRC/32/22 (15 April 2016) and OHCHR, The Human Rights Case against Corruption, HR/NONE/2013/120. 
their human rights obligations or as a direct violation of human rights itself. ${ }^{14}$ There is also a mounting body of literature discussing interlinkages between corruption and human rights. ${ }^{15}$

Nine possible causes of corruption have been prominent in research: the size of the public sector, the quality of regulation, the degree of economic competition, the structure of government, the amount of decentralization, the impact of culture, values and gender, and the role of invariant features such as geography and history. ${ }^{16}$ Particularly in instances of grand corruption ${ }^{17}$ involv-

14 UN Subcommittee for Prevention of Torture, Seventh Annual Report, CAT/C/52/2, 24 February 2014; A/ HRC/40/59, \$76; Final report of the Human Rights Council Advisory Committee on the issue of the negative impact of corruption on the enjoyment of human rights, A/HRC/28/73, 5 January 2015, §17.

15 See e.g. Peters, A., Corruption as a Violation of International Human Rights, The European Journal of International Law, vol. 29, no. 4, 2019, pp. 1251 - 1287; Peirone, F., Corruption as a violation of international human rights: a reply to Anne Peters, The European Journal of International Law, vol. 29, no. 4, 2019, pp. 1297 - 1302; Davis, K. E., Corruption as a Violation of International Human Rights: A Reply to Anne Peters, The European Journal of International Law, vol. 29, no. 4, 2019, pp. 1289 - 1296; Andersen, M. K., Why Corruption Matters in Human Rights, Journal of Human Rights Practice, vol. 10, no. 1, 2018, pp. 179 - 190; Bacio-Terracino, J., Corruption as a violation of human rights, International Council on Human Rights Policy, 2008; Gathii, J., Defining the relationship between human rights and corruption, University of Pennsylvania Journal of International Law, vol. 31, no. 1, 2009, pp. 125 - 202; De Beco, G., Monitoring corruption from a human rights perspective, The International Journal of $\mathrm{Hu}-$ man Rights, vol. 15, no. 7, 2011, pp. 1107 - 1124; Rose, C., The limitations of a human rights approach to corruption, International and Comparative Law Quarterly, vol. 65, no. 2, 2016, pp. 405 - 438; Cardona, L. A.; Ortiz, H.; Vázquez, D., Corruption and Human Rights: Possible Relations, Human Rights Quarterly, vol. 40, no. 2, 2018, pp. 317 - 334; Kim, H. J.; Sharman, J. C., Accounts and Accountability: Corruption, Human Rights, and Individual Accountability Norms, International Organization, vol. 68, no. 2, 2014, pp. 417 - 448; Roksandić Vidlička, S., Prosecuting Serious Economic Crimes as International Crimes, A New Mandate for the ICC?, Dunker\&Humblot, Berlin, 2017, section 6.8. Few of these however mention, let alone comprehensively deal with, the HRC's contribution to fight against corruption.

16 Graf Lambsdorff, J., Causes and consequences of corruption: What do we know from a cross-section of countries?, in: Rose-Ackerman, S. (ed.), International Handbook on the Economics of Corruption, Edward Elgar, Cheltenham, Northampton, 2006, p. 4.

17 Grand corruption refers to the corruption of heads of state, ministers, and top officials and usually involves large amounts of assets - See Anti-Corruption Resource Centre, Corruption Glossary, www.u4.no/document/faqs5.cfm\#grandcorruption; and United Nations Handbook on Practical-Anticorruption Measures for Prosecutors and Investigators, https://www.unodc.org/documents/afghanistan/Anti-Corruption/Handbook_practical_anti-corruption.pdf (5 march 2021). 
ing large-scale diversion and misallocation of government resources through embezzlement and bribery, the State may be deprived of crucial resources thus diminishing its ability to deliver goods and services that are essential to individual survival and well-being ${ }^{18}$ and consequently restricting the State's ability to meet its international human rights obligations. The under-enforcement of law caused by corruption, unless somehow corrected, can eventually result in a failing and then a failed State. ${ }^{19}$

As a transnational phenomenon, it requires international cooperation, including in the field of human rights. The OHCHR promotes a human rights-based approach to anti-corruption, putting the individuals as the 'rights-holders' and the States as the 'duty-bearers' of corresponding obligations in the focus of the anti-corruption debate and efforts at all levels. ${ }^{20} \mathrm{~A}$ number of studies ${ }^{21}$ have also recognized that any anti-corruption efforts need to comply with human rights standards, in order not to lose their legitimacy, since human rights standards, principles and mechanisms provide additional entry points to complement anti-corruption efforts.

Corruption seriously undermines the realisation and enjoyment of human rights protected by numerous international treaties, as well as the functioning of and legitimacy of public institutions and processes and the rule of law. The human rights treaty-based bodies - the Committees - in the context of discharging their mandates increasingly receive significant information on the pernicious impact of corruption on the enjoyment of human rights. Such information mainly comes from civil society groups that provide reports, in particular on countries up for review, but also from individual communications, typically as part of the overall context in which the alleged human rights violation occurred. The Committees have addressed the negative impact of corruption on human

18 Human Rights and Countering Corruption prepared by the Geneva Academy in collaboration with the United Nations High Commissioner for Human Rights, p. 7, available at: https://www.geneva-academy.ch/joomlatools-files/docman-files/Human\%20 Rights\%20and\%20Countering\%20Corruption.pdf (2 March 2021).

19 See Carrington, P. D., Law and Transnational Corruption: The Need for Lincoln's Law Abroad?, Law and Contemporary Problems, vol. 70, no. 4, 2007, p. 111.

20 See, Anti-corruption efforts, OHCHR, https://www.ohchr.org/EN/Issues/Development/ GoodGovernance/Pages/Corruption.aspx (5 February 2021).

21 See, Human Rights and Countering Corruption, op. cit. (fn. 18); The nexus between anti-corruption and human rights, A Review by the Raoul Wallenberg Institute of Human Rights and Humanitarian Law, available at https://rwi.lu.se/publications/nexus-anti-corruption-human-rights/ (2 March 2021); Roksandić Vidlička, S., Filling the void: the case for international economic criminal law, Zeitschrift für die gesamte Strafrechtswissenschaft, vol. 129, no. 3, 2017, pp. $852-884$. 
rights in various instances: especially in the Concluding Observations (COBs), but also in individual communications ${ }^{22}$, and finally, in General Comments (GCs) or recommendations, all of these with a view to provide guidance to States parties on their human rights duties in the context of the challenges posed by corruption.

The aim of this article is to first, briefly present and discuss the negative impact of corruption on the enjoyment of human rights, with a focus on civil and political rights ${ }^{23}$, and States' obligations under the International Covenant on Civil and Political Rights ${ }^{24}$ (ICCPR). The central theme of this article is a critical analysis of the practice of the UN Human Rights Committee (HRC), demonstrating that corruption is no longer only an addition to a sentence in the middle or towards the end of much longer paragraphs of $\mathrm{COBs}^{25}$, but features prominently as a standalone separate concern followed by specific and detailed recommendations. Their inclusion among the initial paragraphs of the respective COBs clearly signals the recognition by the HRC of interlinkages between corruption and serious effects on a number of civil and political rights. The conclusion offers some thoughts on possible further actions within the HRC tackling corruption with the objective of ensuring full realisation and enjoyment of civil and political human rights.

\section{NEGATIVE EFFECTS OF CORRUPTION ON HUMAN RIGHTS AND STATES' OBLIGATIONS UNDER THE INTERNATIONAL COVENANT ON CIVIL AND POLITICAL RIGHTS}

Corruption, as opposed to other crimes, sometimes referred to as a victimless crime - due to the difficulty in identifying personally and directly affected

22 In order to substantiate an individual complaint or communication to the human rights committees, the victim needs to make the argument that corrupt behaviour has in fact violated specific human rights in concrete cases, which faces numerous doctrinal problems. Thus, the committees can, and in fact already do, build corruption into their processes, and they may acknowledge corruption as an aggravating factor of human rights violations, without needing to conceptualize corruption as a human rights violation tout court. See, Peters, A., op. cit. (fn. 15), p. 1285.

23 Since corruption generates discriminations and inequality, this relationship, in the first place, bears on civil and political rights. Arnone, M.; Borlini, L. S., Corruption, Economic Analysis and International Law, Edward Elgar, Cheltenham, Northampton, 2014, p. 170.

24 United Nations, Treaty Series, vol. 999, p. 171 and vol. 1057, p. 407.

25 See the criticism in the 2018 study The nexus between anti-corruption and human rights, op. cit. (fn. 21), p. 2. 
persons, undoubtedly affects, directly or indirectly, individuals, groups and society as a whole.

Failure to act to prevent, stop and remedy corruption may trigger state responsibility under international law if that failure constitutes a breach of an international obligation - for example under the UNCAC ${ }^{26}$ or one of the human rights treaties - and breach is attributable to the state. ${ }^{27}$ An action may be attributable to the state if taken by organs or officials of the state ${ }^{28}$, or private individuals exercising elements of governmental authority ${ }^{29}$, or acting under the state's instructions or under the state's direction or control. ${ }^{30}$ The conduct of State organs or persons exercising governmental authority are attributable to the State even if it represents actions or omissions taken ultra vires. ${ }^{31}$

Corruption adversely affects a number of human rights. Acts of corruption may amount to prohibited forms of discrimination or directly violate individual rights. Pervasive corruption weakens the accountability structures that protect human rights, contributing to impunity, impeding law enforcement and undermining the rule of law. Petty corruption, or everyday abuse of entrusted power by public officials in their interactions with ordinary citizens, has a direct impact on their access to basic goods and services. Corruption also negatively impacts collective rights. Combatting corruption is particularly important to ensure the empowerment, participation and protection of individuals who are members of vulnerable or marginalized groups, including minorities and indigenous peoples. ${ }^{32}$

Human rights are most directly affected where corrupt acts result in or themselves constitute human rights violations involving specific victims. For instance, where the solicitation of an undue advantage involves an element of coercion or necessity. The undue advantage sought may itself amount to a

26 The Conference of States Parties to the UNCAC explored corruption and human rights in 2019 at its eighth session in Abu Dhabi titled Human Rights, Gender and Corruption - linkages, good practices, potential and limitations, https://www.ohchr.org/ EN/Issues/Development/GoodGovernance/Pages/SpecialEventHRGenderCorruption.aspx (25 March 2021).

27 Articles on Responsibility of States for Internationally Wrongful Acts (ARSIWA), Annex to General Assembly resolution 56/83 of 12 December 2001, and corrected by document A/56/49(Vol. I)/Corr.4.

Article 4 ARSIWA.

29 Article 5 ARSIWA.

30 Article 8 ARSIWA.

31 Article 7 ARSIWA.

32 See also Human Rights and Countering Corruption, op. cit. (fn. 18), p. 7. 
human rights violation, as in the case of coerced sexual favors or forced labor. The fulfilment of the undue advantage becomes an illicit condition for accessing public goods and social services or treatment in conformity with what is required under international human rights law. Corruption also manifests in public procurement processes, undermining the quality and availability of public goods and services that underpin the realization of human rights. This form of misconduct, referred to as petty corruption, can result in discriminatory access to social services, education, health care, housing, food and/or official documents, where such services are provided only to those who can afford to pay and disproportionately affects those with fewer available resources.

Moreover, corruption not only affects natural and legal persons who stand outside the corrupt relationship, but adversely impacts society as a whole. For the purposes of this article, focusing on the mandate of the HRC, it is important to note that corruption affects the rights to equality and non-discrimination, since it results in discrimination in access to public services in favour of those who are able to influence the authorities to act in their personal interest. The economically and politically disadvantaged thus suffer disproportionately from the consequences of corruption because they are particularly dependent on public goods. Further, corruption is also an indirect barrier to equality, since by slowing down economic growth and decreasing government revenues, corruption limits the ability of the state to provide essential goods and services and thus disproportionately impacts the poor, particularly marginalized social groups, and thus indirectly aggravates the effects of discrimination. Corruption also compounds social inequalities by increasing the power of elites and giving them more incentives to hold onto power. ${ }^{33}$

Corruption which is systemic in nature also tends to undermine the rule of law, democracy, good governance and the administration of justice. ${ }^{34}$ Some civil and political rights guaranteed under the International Covenant on Civil and Political Rights (ICCPR), such as the right to life, liberty and security of person, due process rights and the right to a remedy, to political participation, to information, to freedom of movement, are more often than others exposed

33 Ibid. and Corruption and Human Rights: Making the Connection, ICHRP and TI, International Council on Human Rights Policy, Geneva, 2009, pp. 7 - 10, available at: www.ichrp.org/files/reports/40/131_web.pdf (5 March 2021).

34 See e.g. Zvekić, U.; Roksandić Vidlička, S., Infrastructure of Integrity - Corruption and Anti-Corruption Pledges in the Western Balkan (Executive Summary), Global Initiative Against Transnational Organized Crime, 2020, available at: https://globalinitiative. net/analysis/corruption-western-balkans/ (14 April 2021). 
to the negative impact of corrupt practices. ${ }^{35}$ Fundamental procedural human rights guarantees, like access to courts, equality of arms or the presumption of innocence can no longer be guaranteed in situations where those involved in administering justice such as judges and court support staff engage in corrupt conduct including bribery, extortion, intimidation, influence peddling and the abuse of court procedures for personal gain. ${ }^{36}$ Corruption also negatively impacts the population's right to participate in public affairs, such as the right to vote, the right to be elected and the right of equal access to public services. ${ }^{37}$ For instance, the manipulation of elections, referenda, or plebiscites through the bribery of voters or corruption of political party officials through campaign contributions, directly violate Art. 25(a) and (b) ${ }^{38}$ of the ICCPR.

Under the the ICCPR, State parties have obligations, including extra-territorial obligations, to respect, protect and fulfil all human rights of all and a failure to exercise due diligence to prevent human rights harm caused by corruption, or to prohibit and prosecute corrupt activities could constitute a violation of States' human rights obligations. ${ }^{39}$

The obligation to respect human rights requires States to avoid measures that hinder or prevent the enjoyment of human rights, which requires the establishment of a democratic system of government that upholds transparency, accountability and the rule of law.

The obligation to protect requires States to take measures that prevent third parties from interfering with the enjoyment of human rights. Where such interference has nevertheless taken place, States are required to ensure that victims, witnesses, whistle-blowers and experts are protected from any intimidation and harm, and have safe, accessible, visible and independent channels for reporting

35 For elaboration of this point see, e.g. Human Rights and Countering Corruption, op cit. (fn. 18), pp. 7 - 9, and Boersma, M., Corruption: A Violation of Human Rights and a Crime Under International Law?, Intersentia, Cambridge, 2012, pp. 202 - 228.

Human Rights and Countering Corruption, op. cit. (fn. 18), p. 8.

37 M. Boersma, op. cit. (fn. 35), p. 220.

38 Art. 25 of the ICCPR - "Every citizen shall have the right and the opportunity, without any of the distinctions mentioned in article 2 and without unreasonable restrictions:

(a) To take part in the conduct of public affairs, directly or through freely chosen representatives;

(b) To vote and to be elected at genuine periodic elections which shall be by universal and equal suffrage and shall be held by secret ballot, guaranteeing the free expression of the will of the electors;..."

See e.g. COBs of the HRC on Angola, CCPR/C/AGO/C/2 (2019). 
corruption, and that perpetrators are held to account by prosecuting such acts of corruption and ensuring that victims have access to appropriate and effective remedies, which includes equal and effective access to justice, procedural guarantees in court proceedings, and adequate, effective and prompt reparation for harm suffered.

The obligation to fulfil requires States to take positive measures that enable individuals and communities to fully enjoy human rights. In the context of corruption, the State is, in particular, responsible for empowering people to enjoy their rights, developing the capacities necessary for the enjoyment of rights, establishing procedures that enable individuals and groups to claim rights violated by corruption and to demand remedies and compensation, and finally to counter corruption as a systemic obstacle to human rights.

In order for States to comply with their obligations under the ICCPR, they are also encouraged to ratify anti-corruption treaties, particularly the UNCAC, and adopt and implement policies aimed at preventing corruption, criminalize acts of corruption and adopt anti-corruption legislation, investigate, prosecute and convict those responsible and provide effective and appropriate remedies to victims. A special emphasis should be given to international cooperation and human rights safeguards within the context of asset return. ${ }^{40}$ States must take all the necessary legislative and administrative measures to ensure implementation of their obligations under $\mathrm{UNCAC}^{41}$, these actions being also inherently part of the State obligations under respective human rights treaties, including the ICCPR. ${ }^{42}$

\section{THE CONTRIBUTION OF THE UN HUMAN RIGHTS COMMITTEE}

The HRC, established as a treaty-based body under the ICCPR in1976, exercises three main functions: ${ }^{43}$ it conducts regular monitoring - review of

40 UNCAC, Chapters IV and V.

${ }^{41}$ UNCAC Chapter I, V and VIII.

42 See e.g., the following COBs of the HRC: Tajikistan, CCPR/C/TJK/CO/3 (2019); Niger, CCPR/C/NER/CO/2 (2019); Equatorial Guinea, CCPR/C/GNQ/CO/1 (2019); Nigeria, CCPR/C/NER/CO/2 (2019); San Marino, CCPR/C/SMR/CO/2 (2008); Azerbaijan, CCPR/C/AZE/CO/4 (2016), Kyrgyzstan, CCPR/C/KGZ/CO/2 (2014) and Uzbekistan, CCPR/C/UZB/CO/4 (2015).

43 See more on the HRC in Civil and Political Rights: The Human Rights Committee, Fact Sheet No. 15 (Rev. 1), OHCHR, Geneva, 2005, available also at: https://www.ohchr. org/Documents/Publications/FactSheet15rev.len.pdf (2 March 2021). 
States parties through "a constructive dialogue"; it decides on individual communications received by individuals alleging violations of their rights under the ICCPR by adopting views; and it drafts and adopts General Comments (GCs), which serve as an interpretation of ICCPR's rights and authoritative guidance for domestic and international courts and other authorities.

The analysis of the HRC practice, especially recent one, rebuts the existing research studies' findings, that the corruption is being addressed by the human rights treaty-based bodies generally in an unsystematic manner, that the first striking feature of the mentions of corruption by the UN human rights treaty bodies in their COBs is their vagueness, that corruption is seldom the central element of the paragraph, and quite often is an addition to a sentence in the middle or towards the end of much longer paragraphs, and that very few of the references to corruption detail what type of corrupt practice is of concern to the Committees. A further reproach is that there exists a lack of reasoning about the links between the corrupt act in question and the human right affected and that such imprecision is problematic because the audience is not informed on why or how, according to the relevant Committee, the issue has been or should be tackled upfront from a human rights perspective. ${ }^{44}$

\subsection{Periodic monitoring of States parties}

The only mandatory compliance procedure for all ICCPR States parties is an obligation to file periodic State reports. States parties undoubtedly view reporting as the least intrusive and most non-confrontational device to promote compliance. $^{45}$

The practice of the HRC demonstrates that the HRC recognises the importance of fighting corruption, and increasingly so, by frequently and systematically including explicit questions on anti-corruption ${ }^{46}$ in States parties' reviews

44 See e.g. The nexus between anti-corruption and human rights, op. cit. (fn. 21), pp. $1-2$ and 21 .

45 Shelton, D. L., Advanced Introduction to International Human Rights Law, Second edition, Edward Elgar, Cheltenham, Northampton, 2020, p. 232.

46 There are also numerous instances where the HRC implicitly tackled issued of corruption, but due to space limitations, they are not included here. See, e.g. Pearson, Z., An international human rights approach to corruption, in: Larmour, P.; Wolanin, N. (eds.), Corruption and Anti-Corruption, ANU Press, Canberra, 2001, pp. 30 - 61. 
under its monitoring function. ${ }^{47}$ Nevertheless, there still exists no systematic and comprehensive theoretical analysis on the HRC's practice on anti-corruption. ${ }^{48}$

The HRC has traditionally expressed concern related to corruption in the context of the right to a fair trial and the independence of the justice system ${ }^{49}$, sometimes linked to the principle of non-discrimination ${ }^{50}$, while in recent years, it has developed a more comprehensive approach to corruption by raising it in different contexts. References have been made to the participation in public affairs $^{51}$, the right to life ${ }^{52}$ (in cases where the death penalty is legal for corrup-

47 See, e.g., the following COBs of the HRC: Tajikistan, CCPR/C/TJK/CO/3 (2019); Niger, CCPR/C/NER/CO/2 (2019); Equatorial Guinea, CCPR/C/GNQ/CO/1 (2019); Nigeria, CCPR/C/NER/CO/2 (2019); Azerbaijan, CCPR/C/AZE/CO/4 (2016); Uzbekistan, CCPR/C/UZB/CO/4 (2015); Kyrgyzstan, CCPR/C/KGZ/CO/2 (2014); Turkmenistan, CCPR/C/TKM/CO/1/Add. 1 (2012); Chad, CCPR/C/TCD/CO/1 (2009); San Marino, CCPR/C/SMR/CO/2 (2008).

48 There are to be found only a few references to the issue in seminal works on the ICCPR, such as in Castan, J., The International Covenant on Civil and Political Rights, Third Edition, Oxford University Press, Oxford, 2013, p. 869; Schabas, W. A., U.N. International Covenant on Civil and Political Rights, Nowak's CCPR Commentary, Third revised edition, N. P. Engel Verlag, Kehl, 2019, pp. 40, 155, 285, 366, 371, 1051; Taylor, P. M., A Commentary on the International Covenant on Civil and Political Rights, The UN Human Rights Committee's Monitoring of ICCPR Rights, Cambridge University Press, Cambridge, 2020, pp. 392 - 393, 492 and 724 - 725.

49 Article 14 ICCPR. See e.g., the following COBs: Central African Republic (CAR), CCPR/C/CAF/CO/3 (2020), paras. 27-28, Mexico, CCPR/C/MEX/CO/6 (2019), para. 40; Paraguay, CCPR/C/PRY/CO/4 (2019), paras. 34-35; and Rwanda, CCPR/C/ RWA/CO/3 (2009), where in para. 17 the HRC expressed its concern that "the gacaca system of justice does not operate in accordance with the basic rules pertaining to the right to a fair trial, particularly with regard to the impartiality of judges and protection of the rights of the accused" and "the lack of legal training for judges and reports of corruption continue to be causes of concern to the Committee".

50 Articles 2 and 26 ICCPR. In COBs on the Former Yugoslav Republic of Macedonia, the HRC commented on the need to combat corruption in order to properly implement article 2, including 2(3); CCPR/C/MKD/CO/2 (2008), para. 8.

51 Article 25 ICCPR. See e.g., the following COBs: Nigeria, CCPR/C/NGA/CO/2 (2019); Bahrain, CCPR/C/BHR/CO/1; Tajikistan, CCPR/C/TJK/CO/3 (2019), and Cabo Verde, CCPR/C/CPV/CO/1/Add.1 (2019).

52 Article 6 ICCPR. See e.g., the following COBs: Thailand, CCPR/C/THA/CO/2 (2017); Bulgaria, CCPR/C/BGR/CO/4 (2018); Burkina Faso, CCPR/C/BFA/CO/1 (2016); Libyan Arab Jamahiriya, CCPR/C/79/Add.101 (1998); Iran, CCPR/C/79/ Add. 25 (1993). 
tion crimes), penitentiary institutions ${ }^{53}$, human trafficking ${ }^{54}$, corruption in the business context ${ }^{55}$, within the management of natural resources ${ }^{56}$ and others. ${ }^{57}$ A more recent trend of regularly raising also concerns about environmental and climate change action that affects human rights, demonstrates that corruption once again oftentimes delays the urgent adaptation and mitigation measures that need to be taken to address the negative effects of climate change. ${ }^{58}$

To illustrate some concrete examples of engaging with the issue of corruption in COBs in the recent years, it is important to note, that the HRC regularly included explicit references to corruption in both, Positive aspects and Principal matters of concern and recommendations parts of the COBs. In the COBs on Uzbekistan the HRC included among positive aspects:

“3. The Committee welcomes the following legislative and institutional measures adopted by the State party:

(e) Establishment of the Economic Crimes and Corruption Unit as part of the Economic Crimes Department of the Office of the Procurator-General, in 2018;

(f) The Anti-Corruption Act, in 2017;"59,

53 Article 7, 9 and 10 ICCPR. See e.g., the following COBs: Nigeria, CCPR/C/NGA/ CO/2 (2019), Guatemala, CCPR/C/GTM/CO/4 (2018); Mexico, CCPR/C/MEX/ CO/6 (2019) and Mauritania CCPR/C/MRT/CO/2 (2019).

54 Article 8 ICCPR. See e.g., the following COBs: Kazakhstan CCPR/C/KAZ/CO/2 (2016); and El Salvador, CCPR/C/SLV/CO/7 (2018).

55 See e.g., the following COBs: Nigeria, CCPR/C/NGA/CO/2, paras. 12-13; Equatorial Guinea, CCPR/C/GNQ/CO/1, paras. 18-19; and Niger, CCPR/C/NER/CO/2, paras. 10-11.

56 See e.g., the following COBs: Equatorial Guinea, CCPR/C/GNQ/CO/1, paras. 18-19; Nigeria, CCPR/C/NER/CO/2, paras. 10-11.

57 Articles 12 (freedom of movement), 17 (right to privacy), article 19 (freedom of expression), 21 (freedom of assembly), 22 (freedom of association) and 24 (rights of the child) ICCPR in the following COBs: Uzbekistan, CCPR/C/UZB/CO/3 (2010); San Marino, CCPR/C/SMR/CO/2 (2008); Tajikistan, CCPR/C/TJK/CO/3 (2019); Azerbaijan, CCPR/C/AZE/CO/4 (2016), Kyrgyzstan, CCPR/C/KGZ/CO/2 (2014), Uzbekistan, CCPR/C/UZB/CO/4 (2015).

58 See e.g., the constructive dialogue with Kenya in March 2021 - COBs are forthcoming.

59 See the COBs on Uzbekistan, CCPR/C/UZB/CO/5 (2020), para. 3. The HRC also welcomed the ratification of the UNCAC by Tunisia on 23 September 2008, see COBs on Tunisia, CCPR/C/TUN/CO/6 (2020), para. 3(e). 
but also expressed its concern and issued a rather detailed recommendation in stand-alone paras. 6 and 7, titled Anti-corruption measures:

"6. While welcoming the anti-corruption reforms and measures undertaken by the State party, the Committee remains concerned at reports of high rates of corruption and bribery, and regrets the lack of information on the investigations, prosecutions and convictions in corruption cases against high-level public officials. It is further concerned that national legislation does not criminalize all internationally recognized corruption offences and all mandatory elements of bribery offences (arts. 2 and 25).

7. The State party should increase its efforts to prevent and eradicate corruption and impunity at all levels, including through the criminalization of all corruption offences and all mandatory elements of bribery offences. It should ensure that all cases of corruption are investigated, and that those responsible are appropriately tried and punished, taking account of the recommendations of the Conference of the States Parties to the United Nations Convention against Corruption regarding the Criminal Code, bribery and misappropriation of funds by public officials." ${ }^{90}$

In fact, the inclusion of stand-alone concerns and recommendation on corruption in COBs has become a rather frequent practice of the HRC when reviewing States parties across the globe. In addition to Uzbekistan, the HRC has in the COBs on Portugal also included the following two paragraphs with very specific and detailed guidance for the State party:

"Anti-corruption measures

8. While appreciating the information provided by the State party on the legislative, institutional and enforcement measures taken to prevent and combat corruption, the Committee is concerned about recent scandals involving high-level cases of corruption in the State party (arts. 1, 2 and 25).

9. The State party should continue its efforts, including through international cooperation and effective implementation of legislation and preventive measures, to combat corruption and promote good governance, transparency and accountability. It should provide relevant training to law enforcement agencies, prosecutors and judges on detecting, investigating and prosecuting corruption, and on strengthening the operational and structural independence and specialization of law enforcement agencies and prosecutors dealing with corruption cases, in order to enable the investigation of complex and high-level corruption cases." ${ }^{\prime 1}$

60 Ibid., para. 6 and 7.

${ }_{61}$ See the COBs on Portugal, CCPR/C/PRT/CO/5 (2020), paras. 8 and 9. 
It demonstrates that the HRC recommends to the State party also to engage in international cooperation to tackle corruption, which can be achieved also under the auspices of the UNCAC - which in its Chapter 4 obliges State parties to cooperate in cross-border criminal matters related to corruption offenses.

In the COBS on Tunisia, the HRC used a slightly different title Combating corruption (as opposed to Anti-corruption measures), and noted with concern:

"13. The Committee notes the various anti-corruption measures taken by the State party, including the adoption of Organic Act No. 59 of 24 August 2017 on the establishment of the Authority for Good Governance and Combating Corruption and the adoption of a national strategy for the period 2016-2020. However, it is concerned at reports that corruption is still common practice in the State party, particularly in the public sector, and that preventive and whistle-blower protection measures are insufficient. It is also concerned at the low number of prosecutions and convictions for corruption. Organic Act No. 62 of 24 October 2017 on reconciliation in the administrative sphere could, moreover, lead to impunity for those guilty of large-scale corruption before 2011 (arts. 2, 14 and 25).",

and issued specific and detailed recommendations:

"14. The State party should:

(a) Intensify its efforts to combat corruption, adopt the draft laws to operationalize the Authority for Good Governance and Combating Corruption, revise and supplement the legal framework to better protect whistle-blowers, and strengthen good governance practices by renewing and monitoring the implementation of the anti-corruption strategy;

(b) Strengthen the capacity of the prosecution service and law enforcement agencies to combat corruption, including through continued training and the provision of adequate resources;

(c) Ensure that all acts of corruption are investigated in an independent and impartial manner and that those responsible, including officials at the highest level of government and other notable figures, are brought to justice and adequately punished, if convicted;

(d) Carry out further awareness-raising campaigns, directed at politicians, government officials, the business sector and the general public, on the economic and social costs of corruption."

In the COBs on CAR, the HRC provided precise guidance on what is expected from the State Party, by recommending:

“28. In the light of the Committee's previous concluding observations (CCPR/C/CAF/CO/2, para. 18), the State party should: 
(a) Fight corruption within the judiciary, including by reforming the Supreme Council of the Judiciary to make it independent of the executive and by strengthening procedures for shielding judges and prosecutors from any form of interference or corruption;..." ${ }^{62}$

In the COBs on Tunisia, the HRC included also a concern regarding the functioning of the transitional justice mechanisms and the work of the Truth and Dignity Commission in investigating serious or gross human rights violations committed between 1955 and 2013, particularly about:

"(a) The insufficient duration of the mandate given to the Commission to report on the human rights violations committed over a period of almost 60 years and to fulfil its tasks in the areas of reparation and combating corruption;". 63

In some countries, national human rights institutions, have taken an active role in combating corruption. ${ }^{64}$ The human rights committees welcome this development, encourage cooperation between these institutions and national anti-corruption bodies, and recommend to these anti-corruption bodies to integrate a human rights-based approach into their work.

There has also been an increase in thematic reports submitted to the HRC on corruption and its negative impact on the enjoyment on human rights by civil society, which serve as valuable sources of information. ${ }^{65}$ The HRC welcomes

62 See COBs on CAR, CCPR/C/CAF/CO/3 (2020), para. 28.

63 see COBs on Tunisia, CCPR/C/TUN/CO/6 (2020), para. 11(a).

64 See, e.g. the Corruption Eradication Commission (KPK) in Indonesia, or the NHRI of Ghana: the Commission on Human Rights and Administrative Justice of Ghana has a three-pronged mandate namely human rights, administrative justice and anti-corruption. As an Anti-Corruption Agency, the Commission investigates allegations of corruption and conflict of interest, abuse of power or office and misuse of public monies in the public sector. The Commission does this by sensitizing the general public about corruption and enlisting public support to fight corruption at all levels of society. See Sondem, S., National Human Rights Institutions The Ghanaian Experience, p. 247, http://studiorum.org.mk/evrodijalog/16/pdf/Evrodijalog_br_16_7_S-Sondem_ENG.pdf (10 March 2021).

65 For example, Rapport thématique sur le lien entre la corruption et les violations des droits humains, Association des journalistes du Burkina, https://tbinternet.ohchr.org/ Treaties/CCPR/Shared\%20Documents/BFA/INT_CCPR_ICS_BFA_41121_F.pdf (10 March 2021); Corruption, human rights and forced labour, $\overline{\mathrm{A}}$ Joint-Submission by Uzbek-German Forum for Human Rights, the International State Crime Initiative, and Tashkent - Demolition, https://tbinternet.ohchr.org/Treaties/CCPR/ Shared\%20Documents/UZB/INT_CCPR_CSS_UZB_41397_E.docx (10 March 2021); and Thematic report on corruption for the review of Tajikistan, Human Rights Centre, 
efforts by civil society to report on corruption and urges governments to take action to prevent corruption from undermining human rights.

\subsection{Individual complaints procedure}

When the HRC dealt with the requirement of the exhaustion of domestic remedies, set out in article 5, paragraph 2 (b), of the Optional Protocol to the ICCPR, in O.K. v Latvia ${ }^{66}$, where the author argued also that the investigation into her son's death was insufficient, and/or a cover-up and that corruption was also involved ${ }^{67}$, but while acknowledging that she has failed to exhaust domestic remedies, she argued, among others, that the widespread corruption prevalent in the police at the time of the death of her son ${ }^{68}$ served as a deterrent to submitting any complaints to the authorities, the HRC observed that "she has failed to substantiate any concrete instance of corruption associated with the investigation into the death of her son" and concluded that the communication is inadmissible.

In most cases of individual complaints reaching the merits phase, the authors argue before the HRC that they had had to bribe public officials in series of events that had led to their fleeing their state of origin and claiming refugee status in another state, and later faced deportation from the latter, or that they suffered violations of their right to fair trial when facing or had faced judicial proceedings on corruption charges. An example of the latter is the case Fanali $v$. Italy ${ }^{69}$, where in special "one-level only" proceedings (i.e. a single instance), the author had been convicted of corruption by the Italian Constitutional Court in connection with the Lockheed scandal. In Adrien Mundyo Busyo et al. v. Democratic

https://tbinternet.ohchr.org/Treaties/CCPR/Shared\%20Documents/TJK/INT_ CCPR_CSS_TJK_35099_E.docx (10 March 2021).

CCPR/C/110/D/1935/2010, para. 7.4.

67 Ibid., para. 3.1.

68 In support of her allegations, the author annexed to her second petition of 11 March 2010 a press article (in The Independent) of 8 November 1999 on a former Latvian secret agent who was seeking asylum in the United Kingdom of Great Britain and Northern Ireland because he had allegedly uncovered corrupt links between senior officials in the Latvian Government and the mafia.

69 Communication No. 75/1980; U.N. Doc. CCPR/C/18/D/75/1980 from 31 March 1983, para. 13. 
Republic of the Congo ${ }^{70}$, the HRC emphasised that judges may not be dismissed on grounds of corruption without proper procedures being followed.

In Kindler v. Canada ${ }^{71}$, the HRC dealing with premeditated murder as "undoubtedly a very serious crime", clarified that death penalty may not be imposed for crimes that do not result directly and intentionally in death, nor for corruption or other economic and political crimes. The HRC thus ruled out the possibility of imposition of the death penalty for any corruptive practices and set clear guarantees for the right to life in article 6 ICCPR.

However, in the case of Couiner Kerrouche v. Algeria the author submitted a complaint that concerned also the alleged acts of corruption leading to a violation of his rights under the ICCPR. ${ }^{72}$ The HRC also recognises that those involved in domestic efforts to investigate, report, prosecute and try corruption are at heightened risk of human rights violations and require effective protection, and takes concerns of corruptive practices into account when dealing with individual communications.

\subsection{General Comments}

General Comments (GCs) by the HRC constitute an additional possible avenue to address corruption and have the potential to carry more significance due to their comprehensiveness. Although they are not legally binding, they carry legal and normative weight. ${ }^{73}$

70 Communication No. 933/2000, U.N. Doc. CCPR/C/78/D/933/2000 from 19 September 2003, paras. 2.1 and 5.2.

71 Communication No. 470/1991, U.N. Doc. CCPR/C/48/D/470/1991 from 11 November 1993, para. 14.3.

72 See, e.g. HRC, CCPR/C/118/D/2128/2012, Couiner Kerrouche v. Algeria, including Individual opinion of Olivier de Frouville, who in para. 4 argues: "It is, moreover, worth noting in the context of this case that, beyond international human rights law, the protection of whistle-blowers finds specific application in the fight against corruption under the terms of the United Nations Convention against Corruption, which was ratified by Algeria on 25 August 2004. Article 33 of this Convention requires States parties to include in their domestic legal systems "appropriate measures to provide protection against any unjustified treatment for any person who reports in good faith and on reasonable grounds to the competent authorities any facts concerning offences established in accordance with this Convention"."

73 See in that regard the pronouncement of the International Court of Justice in the Ahmadou Sadio Diallo (Republic of Guinea v. Democratic Republic of the Congo), Merits, Judgment, I.C.J. Reports 2010, p. 639, para. 66: "Although the Court is in no way obliged, in the exercise of its judicial functions, to model its own interpre- 
There are only two GCs so far, where the HRC explicitly referred to corruption.

In its GC No. 32 on Article 14: Right to equality before courts and tribunals and to a fair trial ${ }^{74}$, the HRC dealt with the issue of dismissal of judges on the charges of corruption and observed that:

"Judges may be dismissed only on serious grounds of misconduct or incompetence, in accordance with fair procedures ensuring objectivity and impartiality set out in the constitution or the law. The dismissal of judges by the executive, e.g. before the expiry of the term for which they have been appointed, without any specific reasons given to them and without effective judicial protection being available to contest the dismissal is incompatible with the independence of the judiciary. The same is true, for instance, for the dismissal by the executive of judges alleged to be corrupt, without following any of the procedures provided for by the law."

GC No. 36 on Article 6: Right to life ${ }^{75}$, contains two explicit references to corruption. First, in para. 23, the HRC explains that the duty to protect the right to life requires States parties to take special measures of protection towards persons in vulnerable situations whose lives have been placed at particular risk because of specific threats or pre-existing patterns of violence and that such persons include, among other, "officials fighting corruption and organized crime", and that "the States parties must respond urgently and effectively in order to protect individuals who find themselves under a specific threat, by adopting special measures such as the assignment of around-the-clock police protection, the issuance of protection and restraining orders against potential aggressors and, in exceptional cases, and only with the free and informed consent of the threatened individual, protective custody." Second, in para. 35 the HRC clarifies, that the term "the most serious crimes" must be read restrictively and appertain only to crimes of extreme gravity involving intentional killing and that crimes not resulting directly and intentionally in death, such as, among others, corruption and other economic and political crimes, although serious in nature, can never serve as the basis, within the framework of article 6 , for the

tation of the Covenant on that of the Committee, it believes that it should ascribe great weight to the interpretation adopted by this independent body that was established specifically to supervise the application of that treaty. The point here is to achieve the necessary clarity and the essential consistency of international law, as well as legal security, to which both the individuals with guaranteed rights and the States obliged to comply with treaty obligations are entitled."

74 CCPR/C/GC/32 (2007), para. 20.

75 CCPR/C/GC/36 (2018). 
imposition of the death penalty, and further, that "States parties are under an obligation to review their criminal laws so as to ensure that the death penalty is not imposed for crimes that do not qualify as the most serious crimes" and "they should also revoke death sentences issued for crimes not qualifying as the most serious crimes and pursue the necessary legal procedures to resentence those convicted for such crimes."

Nevertheless, since the corruption is likely the most effective challenge to the rule of law and democratic society ${ }^{76}$, the issues of corruption are implicitly included in other GCs as well. ${ }^{77}$

Often before embarking on the exercise of drafting a General Comment on a specific right or an issue under the ICCPR, any Committee needs to have already examined these issues extensively and methodically in COBs, and given the above analysis of COBs and incremental steps to tackle certain aspects of corruption in two out of 37 GCs, it seems that the HRC is slowly, but surely, building up relevant practice.

\section{CONCLUSIONS}

No country is entirely free from corruption and there is no simple and single way to eradicate it. It is thus paramount that also the human rights treaty-bodies continue to engage with the States parties on issues of corruption in all instances of negative impacts on human rights. This seems to apply in every monitoring process, through a tailored approach, taking into account specific circumstances of each individual State party ${ }^{78}$ In any case the consideration of corruption needs to take place from the very beginning of the review, already by inclusion of inquiries on anti-corruption measures in the List of Issues or List of Issues Prior to Reporting, despite the imperative constraints in length of these documents, allowing only for a limited number of issues and prescribed number of words, which mandates prioritization. Such inclusion at an early

76 See e.g. Arnone, M.; Borlini, L. S., op. cit. (fn. 23), p. 170.

77 See e.g. GC No. 37 on the right of peaceful assembly (article 21), CCPR/C/GC/37 (2020), where the HRC in para. 40 observes: "Article 21 provides that any restrictions must be "necessary in a democratic society". Restrictions must therefore be necessary and proportionate in the context of a society based on democracy, the rule of law, political pluralism and human rights, as opposed to being merely reasonable or expedient."

78 In some States parties, corruption in places of detention could be prioritized, in others, the focus might be placed on measures to detect, investigate and prosecute corruption affecting asylum-seekers, or on addressing corruption affecting climate mitigation measures, which consequently undermines human rights. 
stage can serve as a basis for civil society organisations, national human rights institutions and other domestic actors to push for action or reforms at domestic level and for advocacy work at the international level throughout the reporting cycle. It also encourages submission of timely shadow reports, which can play a key role in bringing information that is specific and strategic enough to the attention by the HRC.

Moreover, when selecting the COB's concerns and recommendations for the follow-up process, where the two main criteria guide each such selection, namely that ( 1 ) the recommendation is implementable within a year after its adoption, and (2) it requires immediate attention because of the level of gravity of the referred situation and/or the emergency of the situation (e.g. it is a major obstacle for the implementation of the ICCPR or the lack of intervention could threaten the life or security of one or various persons, or the issue has been pending for a long time and has not been addressed by the State party), one rarely finds an issue tackling corruption. But if the HRC recognizes that the corruption represents the main inhibitor for successful implementation of particular rights, it could perhaps keep in mind also to draft particular recommendations in a way that would allow the State party to take action or adopt measures within a year following the review and thus promptly contribute to turning the inhibiting environment into a stimulating one for the full realization of fundamental civil and political rights.

A growing number of governments take seriously their obligation to submit comprehensive reports and respond to committee questions and comments on both the de jure and de facto human rights situations within their borders. ${ }^{79}$

It is reasonable to expect that in the years to come, the HRC is to be confronted with more instances of strategic litigation. ${ }^{80}$ Particularly following transitions to democracy, strategic human rights litigation can play an important role. Analysis of the role of litigation in countries of Central and Eastern Europe suggests that strategic litigation has proved to be a useful tool in developing human rights protection. ${ }^{81}$ The idea of a human rights based approach to anti-corruption

79 Shelton, D. L., op. cit. (fn. 44), p. 235.

80 Strategic litigation can be understood as the act of bringing selected cases to national courts or international judicial or quasi-judicial bodies, with the aim that it will bring about changes in law, or in practice, or create public awareness about the issues at stake in the case. Cases are not chosen randomly, but rather with a certain advocacy goal, and in the public interest, in the sense that the result would vindicate the rights of persons beyond those named in the cases. See The nexus between anti-corruption and human rights, op. cit. (fn. 21), p. 18.

81 Duffy, H., Strategic Human Rights Litigation, Understanding and Maximising Impact, Hart, Oxford, 2018, p. 77. 
practice puts victims at the centre and strategic litigation might clarify some important questions, including on the determination of the issue who the victims of corruption are and how reparations are to be envisaged and implemented.

One important aspect, not yet addressed by the HRC in its practice of tackling corruption, is that women represent a large proportion of the world's poorest and most marginalised people in some societies and are thus amongst those who are hardest hit by the scourge of corruption. Gender roles and stereotypes can also disproportionately affect women resulting in them having to pay more bribes to obtain public services, in violation of their human rights. Moreover, where women remain the primary caretakers of the family, they can be regularly confronted with corruption when accessing public services such as health, education, water and sanitation and the bribes they are forced to pay for obtaining these basic services may often represent a larger percentage of their income compared to men, thus reinforcing the vicious cycle of poverty. There is also evidence that exploitation of the human body, sexually or otherwise, is used as a currency in certain forms of corruption.

While so far NGOs in their interactions with the HRC rarely focus on the issue of corruption as such, they often raise concerns about corruptive environment inhibiting the implementation of human rights generally or in relation to a specific human right. Perhaps in the future, also through amicus curiae briefs, the HRC might be faced with different approaches by the NGOs and civil society organisations.

Moreover, corruption is increasingly transnational in character, and any effective strategy to combat it needs to be context-specific, comprehensive and often requires international cooperation. The HRC already noted that States' current commitments are insufficient and recommended stronger actions. The HRC might, where appropriate, also recommend to States to support efforts to facilitate the return of stolen assets to their country of origin. ${ }^{82}$

All human rights treaty bodies, but particularly the HRC is struggling with rising caseload and without additional resources, which have only slowly been forthcoming, it faces an ever-increasing backlog of petitions, increasing the time applicants must wait for a decision.

The suggestion to take into consideration the impact of corruption on all human rights and developing a joint General Recommendation or Comment on human rights and corruption jointly by various committees ${ }^{83}$, might still be

82 See Draft OHCHR Guidelines on a Human Rights Framework for Asset Recovery, https:// www.ohchr.org/Documents/Issues/Development/CFI-Frameworkforassetrecovery/ Draft_OHCHR_Guidelines_HR_Asset_Recovery.pdf (5 April 2021).

83 See The nexus between anti-corruption and human rights, op. cit. (fn. 21), p. 22. 
a rather distant possibility, however devoting one of the upcoming GCs of the HRC to the issues of corruption seems to be more probable future development.

The HRC by providing guidance to States parties, recommending them necessary legislative, policy and other measures to effectively prevent and suppress corruption, to mobilize resources to fight against corruption and ensure full reparations to victims of corruption, can importantly contribute to efforts directed towards elimination of corruption as a major inhibitor of human rights. However, all of these efforts would become significantly more impactful, if the relevant stakeholders commit to ensure also a wider dissemination of the HRC' decisions among all relevant actors, thus gaining greater visibility and public awareness, including among the general public. A higher awareness, would in turn, also lead to the issues of corruption being raised more consistently by the HRC and other human rights mechanisms.

\section{BIBLIOGRAPHY}

Ahmadou Sadio Diallo (Republic of Guinea v. Democratic Republic of the Congo), Merits, Judgment, I.C.J. Reports 2010, p. 639.

Andersen, M. K., Why Corruption Matters in Human Rights, Journal of Human Rights Practice, vol. 10, no. 1, 2018, pp. 179-190.

Anti-corruption efforts, OHCHR, https://www.ohchr.org/EN/Issues/Development/ GoodGovernance/Pages/Corruption.aspx (5 February 2021).

Arnone, M.; Borlini, L. S., Corruption, Economic Analysis and International Law, Edward Elgar, Cheltenham, Northampton, 2014.

Articles on Responsibility of States for Internationally Wrongful Acts (ARSIWA), Annex to General Assembly resolution 56/83 of 12 December 2001, and corrected by document A/56/49(Vol. I)/Corr.4.

Bacio-Terracino, J., Corruption as a violation of human rights, International Council on Human Rights Policy, 2008, International Council on Human Rights Policy, available at SSRN: https://ssrn.com/abstract=1107918 (5 March 2021).

Boersma, M., Corruption: A Violation of Human Rights and a Crime Under International Law?, Intersentia, Cambridge, 2012.

Cardona, L. A.; Ortiz, H., Vázquez, D., Corruption and Human Rights: Possible Relations, Human Rights Quarterly, vol. 40, no. 2, 2018, pp. 317-334.

Carrington, P. D., Law and Transnational Corruption: The Need for Lincoln's Law Abroad?, Law and Contemporary Problems, vol. 70, no. 4, 2007, pp. 109-138, available at: http://scholarship.law.duke.edu/lcp/vol70/iss4/2 (5 March 2021). 
Castan, J., The International Covenant on Civil and Political Rights, Third Edition, Oxford University Press, Oxford, 2013.

Civil and Political Rights: The Human Rights Committee, Fact Sheet No. 15 (Rev. I), OHCHR, Geneva, 2005, available also at: https://www.ohchr.org/Documents/ Publications/FactSheet15rev.len.pdf (2 March 2021).

Corruption and human rights, https:/www.ohchr.org/EN/Issues/Development/ GoodGovernance/Pages/Corruption.aspx (5 February 2021).

Corruption, human rights and forced labour, A Joint-Submission by Uzbek-German Forum for Human Rights, the International State Crime Initiative, and Tashkent - Demolition, https://tbinternet.ohchr.org/Treaties/CCPR/Shared\%20 Documents/UZB/INT_CCPR_CSS_UZB_41397_E.docx (10 March 2021).

Davis, K. E., Corruption as a Violation of International Human Rights: A Reply to Anne Peters, The European Journal of International Law, vol. 29, no. 4, 2019, pp. 1289-1296.

De Beco, G., Monitoring corruption from a human rights perspective, The International Journal of Human Rights, vol. 15, no. 7, 2011, pp. 1107-1124.

Draft OHCHR Guidelines on a Human Rights Framework for Asset Recovery, https:// www.ohchr.org/Documents/Issues/Development/CFI-Frameworkforassetrecovery/Draft_OHCHR_Guidelines_HR_Asset_Recovery.pdf (5 April 2021).

Duffy, H., Strategic Human Rights Litigation, Understanding and Maximising Impact, Hart, Oxford, 2018.

Final Report on the negative impact of corruption on the enjoyment of human rights, A/ HRC/28/73 (5 January 2015).

Gathii, J., Defining the relationship between human rights and corruption, University of Pennsylvania Journal of International Law, vol. 31, no. 1, 2009, pp. 125-202.

Graf Lambsdorff, J., Causes and consequences of corruption: What do we know from a cross-section of countries?, in: Rose-Ackerman, S. (ed.), International Handbook on the Economics of Corruption, Edward Elgar, Cheltenham, Northampton, 2006, pp. 3-51.

Human Rights, Gender and Corruption - linkages, good practices, potential and limitations, the Conference of States Parties to UNCAC, https://www.ohchr.org/ EN/Issues/Development/GoodGovernance/Pages/SpecialEventHRGenderCorruption.aspx (25 March 2021).

Human Rights Council Resolution 31/14 on 'The role of good governance in the promotion and protection of human rights', $\mathrm{A} / \mathrm{HRC} / \mathrm{RES} / 31 / 14$ (23 March 2016).

International Covenant on Civil and Political Rights (New York, 16 December 1966), United Nations, Treaty Series, vol. 999, p. 171 and vol. 1057, p. 407. 
Kim, H. J.; Sharman, J. C., Accounts and Accountability: Corruption, Human Rights, and Individual Accountability Norms, International Organization, vol. 68, no. 2, 2014, pp. 417-448.

Lucchini, R., Universalisme et relativisme dans l'approche de la corruption. L'envers des droits de l'homme, Editions Universitaires Fribourg Suisse, Fribourg, 1995.

OHCHR, Best practices to counter the negative impact of corruption on the enjoyment of all human rights, $\mathrm{A} / \mathrm{HRC} / 32 / 22$ (15 April 2016).

OHCHR, The Human Rights Case against Corruption, HR/NONE/2013/120.

Pearson, Z., An international human rights approach to corruption, in: Larmour, P.; Wolanin, N. (eds.), Corruption and Anti-Corruption, ANU Press, Canberra, 2001, pp. 30-61.

Peirone, F., Corruption as a violation of international human rights: a reply to Anne Peters, The European Journal of International Law, vol. 29, no. 4, 2019, pp. 1297-1302.

Peters, A., Corruption as a Violation of International Human Rights, The European Journal of International Law, vol. 29, no. 4, 2019, pp. 1251-1287.

Rapport thématique sur le lien entre la corruption et les violations des droits humains, Association des journalistes du Burkina, https://tbinternet.ohchr.org/Treaties/ CCPR/Shared\%20Documents/BFA/INT_CCPR_ICS_BFA_41121_F.pdf (10 March 2021).

Report of the Working Group on Arbitrary Detention, A/HRC/10/21 (16 February 2009).

Resolution adopted by the General Assembly on 17 December 2018, Special session of the General Assembly against corruption, A/RES/73/191.

Roksandić Vidlička, S., Prosecuting Serious Economic Crimes as International Crimes, A New Mandate for the ICC?, Dunker\&Humblot, Berlin, 2017.

Roksandić Vidlička, S., Filling the void: the case for international economic criminal law, Zeitschrift für die gesamte Strafrechtswissenschaft, vol. 129, no. 3, 2017, pp. 852-884.

Rose-Ackerman, S. (ed.), International Handbook on the Economics of Corruption, Edward Elgar, Cheltenham, Northampton, 2006.

Rose, C., International Anti-Corruption Norms, Their Creation and Influence on Domestic legal Systems, Oxford University Press, Oxford, 2015.

Rose, C., The limitations of a human rights approach to corruption, International and Comparative Law Quarterly, vol. 65, no. 2, 2016, pp. 405-438.

Schabas, W. A., U.N. International Covenant on Civil and Political Rights, Nowak's CCPR Commentary, Third revised edition, N. P. Engel Verlag, Kehl, 2019. 
Sharman, J. C., Accounts and Accountability: Corruption, Human Rights, and Individual Accountability Norms, International Organization, vol. 68, no. 2, 2014, pp. 417-448.

Shelton, D. L., Advanced Introduction to International Human Rights Law, Second edition, Edward Elgar, Cheltenham, Northampton, 2020.

Sondem, S., National Human Rights Institutions - The Ghanaian Experience, http:// studiorum.org.mk/evrodijalog/16/pdf/Evrodijalog_br_16_7_S-Sondem_ENG. pdf (10 March 2021).

Taylor, P. M., A Commentary on the International Covenant on Civil and Political Rights, The UN Human Rights Committee's Monitoring of ICCPR Rights, Cambridge University Press, Cambridge, 2020.

The Human Rights Council Advisory Committee's "Study on utilizing non-repatriated illicit funds with a view to supporting the achievement of the Sustainable Development Goals", A/HRC/43/66.

Thematic report on corruption for the review of Tajikistan, Human Rights Centre, https://tbinternet.ohchr.org/Treaties/CCPR/Shared\%20Documents/TJK/ INT_CCPR_CSS_TJK_35099_E.docx (10 March 2021).

The Special Rapporteur on the independence of judges and lawyers, A/72/140 and $\mathrm{A} / 67 / 305$.

The Special Rapporteur on the promotion and protection of the right to freedom of opinion and expression, $\mathrm{A} / 70 / 361$.

The Special Rapporteur on the right of everyone to the enjoyment of the highest attainable standard of physical and mental health, A/72/137.

The Independent Expert on the effects of foreign debt and other related international financial obligations of States on the full enjoyment of all human rights, particularly economic, social and cultural rights, A/HRC/31/61.

The Working Group on Business and Human Rights, A/HRC/44/43.

Transforming our world: the 2030 Agenda for Sustainable Development, A/RES/70/1 (25 September 2015).

United Nations Convention against Corruption (New York, 31 October 2003), United Nations, Treaty Series, vol. 2349, No. 42146, p. 41

United Nations Handbook on Practical-Anticorruption Measures for Prosecutors and Investigators, https://www.unodc.org/documents/afghanistan/Anti-Corruption/ Handbook_practical_anti-corruption.pdf (5 March 2021).

Zvekić, U.; Roksandić Vidlička, S., Infrastructure of Integrity - Corruption and Anti-Corruption Pledges in the Western Balkan (Executive Summary), Global Initiative Against Transnational Organized Crime, 2020, available at: https:// globalinitiative.net/analysis/corruption-western-balkans/ (14 April 2021). 
Sažetak

\section{Vasilka Sancin*}

\section{KORUPCIJA KAO VAŽNA ZAPREKA OSTVARENJA LJUDSKIH PRAVA: ODGOVOR UN-ova ODBORA ZA LJUDSKA PRAVA}

Prepoznajući da korupcija postoji u svim zemljama, neovisno o ekonomskom ili političkom sustavu i njihovu stupnju razvijenosti, u članku se najprije kratko razmatra negativni utjecaj korupcije na ostvarenje ljudskih prava, posebno građanskih i političkih prava, te se skiciraju obaveze država stranaka prema Međunarodnom paktu o građanskim i političkim pravima (ICCPR). Središnja je tema kritička analiza prakse UN-ova Odbora za ljudska prava (HRC), koji je osnovan kao ugovorno tijelo na temelju ICCPR-a 1976. godine, kroz njegove tri glavne funkcije: monitoring - nadzor nad državama strankama kroz "konstruktivni dijalog"; usvajanje odluka (stavova) o pojedinačnim komunikacijama i razvijanje općih komentara, koji služe kao tumačenja prava ICCPR-a i mjerodavne smjernice za domaće i međunarodne vlasti. Dokazuje se da se korupcija više ne spominje samo povremeno u puno dužim odlomcima zaključnih zapažanja, već se naglašava na istaknutom mjestu, često kao samostalno istaknuto zapažanje, nakon čega slijede konkretne i detaljne preporuke. Takav razvoj događaja upućuje na to da HRC prepoznaje važne poveznice između korupcije i ozbiljnih učinaka na niz prava ICCPR-a. U zaključku su ponuđena neka razmišljanja o mogućem razvoju pristupa pitanju u okviru HRC-a, također prepoznajući transnacionalni karakter korupcije, zbog čega svaka učinkovita strategija borbe protiv nje mora biti specifična za kontekst, sveobuhvatna i često zahtijeva međunarodnu suradnju. HRC davanjem smjernica državama strankama, preporučujući im potrebne zakonodavne, političke i druge mjere za učinkovito sprečavanje i suzbijanje korupcije, mobilizaciju resursa za borbu protiv korupcije i osiguravanje pune reparacije za žrtve korupcije, može znatno pridonijeti naporima usmjerenima na uklanjanje korupcije kao glavnog inhibitora ljudskih prava s ciljem osiguravanja njihova punog ostvarenja i uživanja.

Ključne riječi: ljudska prava, korupcija, Međunarodni pakt o građanskim i političkim pravima, UN-ov odbor za ljudska prava, Konvencija Ujedinjenih naroda protiv korupcije

* Dr. sc. Vasilka Sancin, izvanredna profesorica Pravnog fakulteta Sveučilišta u Ljubljani, Poljanski nasip 2, 1000 Ljubljana, Slovenija; vasilka.sancin@pf.uni-lj.si;

ORCID ID: oricd.org/0000-0002-1623-7278 